\title{
Sosyal Medyada Ve Diğer Bazı Mecralarda Yayınlanan Reklamların Tüketiciler Üzerindeki Etkililiği Ve Algılanışı Üzerine Bir Araştırma
} DOI: $10.26466 /$ opus.707041

\author{
Alpaslan Doğan * - İpek Fatma Çevik ** \\ * Dr. Öğr. Üyesi, Iğdır Üniversitesi, İktisadi ve İdari Bilimler Fakültesi, İşletme Bölümü \\ E-Posta: alpaslandogan@hotmail.com ORCID: 0000-0003-0859-984X \\ ** Dr. Öğr. Üyesi, Iğdır Üniversitesi, Güzel Sanatlar Fakültesi, Grafik Bölümü \\ E-Posta: ipekfatmacevik@gmail.com ORCID: 0000-0003-4917-6675
}

\begin{abstract}
Öz
Reklam, sosyal ve ticari alanın önemli konularından birisidir. Reklam verenler önemli beklentilerle önemli maliyetlere katlanmaktadırlar. Reklamların etkinliği, reklam mecralarına göre farkl demografik grupların bu etkinliğe ilişkin algılarının araştırıldığı çalışmada sosyal medyada zorunlu olarak izlettirilen reklamların tüketiciler üzerindeki algıları da incelenmiştir. Araştırma, sosyal medya ve diğer mecralarda yayımlanmakta olan çeşitli türden reklamların, tüketicilerin alım kararları üzerindeki etkisi ile reklamların sunuluş biçimleri karşındaki davranışlarını ortaya çıkarmayı amaçlamaktadır. Kantitatif niteliğindeki araştırma, soru formu aracılığı ile birincil tür veriler elde edilerek yapılmıştır. Araştırmaya 442 katılım sağlanmış, geçerlilik ve güvenirlik testleri neticesinde kullanılan ölçeğin geçerli ve güvenilir olduğuna kanaat getirilmiştir. Araştırma bulgularına göre, sosyal medya mecralarında zorunlu olarak izletilen reklamların büyük oranda olumsuz tepkilerle karşılandığı gözlemlenmiştir. Ayrıca genel olarak reklamlarda iletilenin gerçekliğinden şü̈he duyulmasının, satın alma kararın etkilediği tespit edilmiştir. Reklam mecralarına göre en etkin ve yoğun iletimin sosyal medya mecralarl, en az etkinliğin ise doğrudan, SMS-E-posta, afiş-billboard ve yazılı basın kanalından olduğu da bir başka gözlemdir. Öte yandan reklam konusu itibari ile en fazla giyim ve teknoloji konulu reklamlara ilgi duyulduğu da tespit edilmiştir.
\end{abstract}

Anahtar Kelimeler: Reklam, tüketici reklam algısı, sosyal medya reklamlarl, zorunlu sosyal medya reklamlart. 


\title{
A Research On The Effectiveness And Perception Of Advertising Advertisements On Social Media And Some Media
}

\begin{abstract}
Advertising is one of the important issues in the social and commercial area. Advertisers bear significant costs with important expectations. The effectiveness of advertisements and the perceptions of different demographic groups according to the advertising channels were investigated, and the perceptions of the advertisements that were forced to be watched on social media were examined. The research aims to reveal the effects of various types of advertisements published on other social media platforms on consumers' purchasing decisions and their behavior towards the presentation of advertisements. The quantitative research was carried out by obtaining primary type data via the questionnaire. 442 participants participated in the research and it was concluded that the scale used as a result of validity and reliability tests was valid and reliable. According to the findings of the research, it has been observed that the advertisements that are obligatoryly watched on social media platforms are mostly met with negative reactions. In addition, it was determined that the suspicion of the authenticity of the advertisements in general affects the purchase decision. It is another observation that the most effective and intense transmission according to advertising channels is social media platforms and the least activity is directly from SMS, E-mail, banner-billboard and print media. On the other hand, it has been determined that the most interest in advertising on clothing and technology is in terms of advertising.
\end{abstract}

Keywords: Advertising, consumer advertising perception, social media ads, mandatory social media ads. 


\section{Giriş}

Reklam işletmeler ve toplum için önemli faaliyetlerden birisidir. Öte yandan reklam yayın mecraları da giderek çeşitlenmektedir. Bunların önemlilerinden birisi de sosyal medya mecralarında yayınlanan reklamlardır. Çalışma ile sosyal medya ve diğer platformlarda yayımlanmakta olan çeşitli türden reklamların, tüketicilerin alım kararları üzerindeki etkisi ile reklamların sunuluş biçimleri karşındaki davranışlarını ortaya çıkarmayı amaçlamaktadır. Sosyal medya reklamlarında zorunlu olarak izletilen reklamlara yönelik algılar araştırılmıştır. Çalışmanın reklam verenler, yayınlayanlar ve tüketiciler için önemli olduğu düşünülmektedir.

\section{Reklam}

Reklam, Latince'de 'advertere' fiilinden türeyen ve bir şeye yönelmek anlamina gelen bir kelimedir (Goddard, 2001; Fidan, 2007, s.106). Reklam tan1mını belirli bir ücret karşılığı, belirli kişi ya da kişiler tarafından bir mecrada belirli bir süre boyunca yapılan, kurum, kişi, yer, mekân, ürün ya da fikrin bir amaca yönelik bilgilendirmeleri olarak ifade eder. Bir diğer reklam tanımında, bir marka, mal veya hizmetin varlığını tüketicilere duyurarak olumlu bir tutum oluşturmayı hedefleyen mesajlar oluşturmak ve bu mesajları belirli bir ücret karşılığı ile medya mecralarında yayınlanması olarak ifade edilir (Küçükerdoğan, 2009, s.7). Benzer diğer bir reklam tanımı da gönüllü bir şekilde tüketiciyi belirli bir düşünceye yönelterek belirli bir davranışa ikna etmek, tüketicinin dikkatini reklama konu olan ürüne çekmek amacı ile hazırlanan iletişim araçları kullanılarak duyurulan bilgilerdir (Gülsoy, 1999, s.9). Rutherford ise reklamın ikna etme amacı taşıdığını, üretici ve tüketici arasinda köprü oluşturarak tüketicinin gönüllü bir şekilde satın alma davran1şında bulunmaya yönlendirdiğini söyler (Rutherford ve Gerçekler, 1996: 16). Reklam için yapılan bir başka tanımda, basit mesajlarla büyük kitlelere ulaşarak, belirli bir maliyet ile markaya değer kazandırma işlevi olarak açıklanır (Ring, 1996, s.31). Ürüne diğerlerinden farklı anlamlar yüklenerek, güzel söz, ses, görsel ve görüntüler kullanılarak oluşturulan reklam aracılığ 1 ile markalar yaratılır. Kısaca reklam, tüketiciyi reklamı yapılan ürünle ilgili bilgilere ikna etmeyi amaçlar (Weilbacher, 2001). 
İşletmeler için büyük önem taşıyan reklam, tüketiciyle iletişim kurmanın en iyi yoludur (Kannan ve Tyagi, 2013). Tüketicinin, var olan marka ve ürünler hakkında yerleşmiş tercihlerini değiştirebilir, satın alma kararlarına büyük ölçüde etki edebilir (Giri, 2015). Bugün, var olan iletişim teknolojileri ile tüketiciler, üretim noktası uzakta olan her türlü farklı marka ve ürünleri fiyatlarına, özellik ve kalitelerine göre bir tuş ile karşılaştırma yaparak beklentilerine cevap veren en uygun ürüne kolayca ulaşabilmektedir (Uusitalo, 2010). Üretici ve tüketici arasındaki mesafelerin iletişim teknolojileri ile ortadan kalkması, konvansiyonel reklamın da dönüşerek dijital mecralara yayılmasını hızlandırdığı, bu noktada pazarlamada rekabetin hız kazandığı ve reklamın işletmeler için vazgeçilmez bir araç olduğu görülür. Bu çerçevede reklamın pazarlama çalışmalarının bir bileşeni olarak da ortaya çıtığı görülür (Yaylacı, 1999, s.4). Pazarlama süreci içerisinde değerlendirilen reklam ayrıca bilgi verme ve ikna etme yönleri ile kitle iletişim şekli olarak da ele alınır (Gürüz, 1999, s.20). Bir reklamın başarılı olup olmadığı tüketiciye verilmek istenen bilgilerin doğru zamanda ve doğru iletişim mecrasında yayınlanması ile hedeflenen tüketici kitlesindeki tutum ve davranış değişiklikleri ile ölçülebilir (Weilbacher, 2001). Tüm bu bilgiler doğrultusunda reklamın özellikleri şöyle özetlenebilir; reklam pazarlama ve iletişimin bir şeklidir. Tüketici ve işletmeler arasında bir köprü görevi görür, tüketiciyi ikna etmeye çalışarak satın alma arzusu oluşturur. Reklamı yapan kişi, kurum, kuruluş bellidir ve reklamda ürün, hizmet, vaat, ödül ve sorunlara çözüm içerir.

\section{Reklam Amacı}

İşletmelere ait ürün ya da hizmetlerin satışını ve buna bağlı olarak karlılığını artırmayı hedefleyen reklam, üretici ve tüketiciye yönelik amaçlar taşır. Bunun yanı sıra işletmenin imajını oluşturarak geleceğini de belirlemesine yardımcı olur. Pazarlama Yönetimi isimli kitabında Kotler, reklamın amaçlarını bilgilendirmek, ikna etmek ve hatırlatmak olarak üç başlıkta toplamıştır (Kotler, 2003, s.29). Bilgilendirme, reklama konu olan ürün ya da hizmetin içerik, kullanım alanları ve fiyatı hakkında tüketiciyi haberdar etmek olarak ifade eder. Bu ifadeye göre ürünü tanıtmak, ürünün kullanım şekilleri, nasıl çalıştığı, fiyat değişiklikleri ve sunulan hizmetler hakkında bilgi vermenin yanı sura tüketici endişelerini gidererek işletmeye olumlu imaj oluşturmak ve tüketiciyi eğitmek reklamın amacı olan bilgilendirmenin konusunu oluşturur. 
Kotler, ikna etmeyi, ürün ya da hizmet ile ilgili tüketicinin düşüncelerini değiştirerek satın almaya ikna etmek olarak tanımlar. İkna etmenin içeriğini markaya bağlllık oluşturmak, markaya özendirmek, ürünle ilgili algıları değiştirmek ve satın almaya yönelterek ürünün siparişini vermeye ikna etmek oluşturur. Hatırlamak amacinda ise reklamı yapılan ürün ya da hizmeti belirli bir süre boyunca tüketicinin hatırlamasını sağlamak olarak ifade eder. Reklamı yapılan ürüne ihtiyaç duyulacağını, nereden satın alınabileceğini ve bu nedenle tüketicinin sürekli bu ürünü hatırlamalarını sağlamayı amaçlar. Böylece reklamın hedeflediği tüketici kitlesi istenilen yönde tutum ve davranışlarında değişim gösterir.

Reklamın amaçları ekonomik, psikolojik, satış, iletişim ve özel amaçlar olarak da ayrıca ele alınabilir. Ürün ya da hizmetin satışı, kullanılması ve faydalanmasının sağlanması reklamın ekonomik amacı olarak söylenebilir. Talep edilenden daha fazla ürün olması ve ürünün alternatiflerinin bulunması sonucu oluşan rekabet ortamı ile reklamın ekonomik açıdan önemi ortaya çıkar. Bu durumda reklam, tüketici için olduğu kadar işletmeler için de önem taşır. Farklı fiyat ve ürün özellikleri taşıyan alternatiflerinden haberdar olan tüketici ile satılmak istenen ürün arasındaki etkin iletişim aracı reklamdır. Tercihli talebin oluşması için reklam hem işletmenin hem de tüketicinin amaçlarına hizmet eder.

Reklamın psikolojik amacı, tüketiciyi bir markayı ihtiyacı dışında olsa bile satın alarak arzularını gerçekleştireceğine, başkaları tarafından daha çok sevileceğine, saygı kazanacağına inandırmayı ve bu yönde davranışlar göstermelerini amaçlar. Satın alma davranışında bulunan tüketici, toplumdaki rolünü ve yerini sembolik olarak sağladığına inanarak psikolojik bir tatmin yaşar. Reklam ise psikolojik amacını gerçekleştirmiş olur.

Satış amacı güden reklam, tüketicinin reklamı yapılan ürün ya da hizmetle ilgili tutum ve düşüncelerini değiştirerek uzun ve kısa vadede satın almasını sağlamayı amaçlar (Gün, 1999, s.25). Marka bilinirliğini ve pazar payını artırarak uzun vadede olumlu marka imajı oluşturmak ve buna ikna etmek; kısa vadede ise hedeflenen tüketici kitlesinin kısa sürede satın almaya yönlendirmek (doğrudan reklam) satış amacı güden reklamın işlevini tanımlayabilir (Kocabaş ve Elden, 1997, s.26). Her iki durumda da reklam tüketiciye ya da aracıya bilgi verir ve yardımcı olur; talep oluşturur ve satışı artırır.

Reklamın tüm amaçlarının yerine getirilebilmesi için tüketici ile iletişim kurulması gerekmektedir. Bu aşamada ikna özelliği ile reklamın iletişim 
amacı söz konusu olacaktır. Markaya dikkat çekerek, farkındalık oluşturarak imajını istenilen şekilde değiştirmek ve tüketicide olumlu bir tutum yaratma amacı üzerine yoğunlaşan reklam, bir iletişim süreci oluşturur. Bu iletişim süreci, marka hakkında farkındalık, marka hakkında olumlu tutum ve düşünce, olumlu tutum ile düşünceleri destekleyen ve eğlendiren reklamlar olarak dört aşamada ele alınabilir.

Reklamın ekonomik, psikolojik, satış ve iletişim amaçlarının dışında özel amaçları da bulunabilir. İndirim, hediye, çekiliş ve promosyon gibi pratiklerle satın alma davranışını hızlandırmak; bayramlar, özel gün ve haftalar ile satın alma arasında bağlantı kurarak satışı artırmak; satın alma davranışını hatırlatmak reklamın özel amaçları olarak sayılabilir. Bunun yanı sıra markaya karşı duygusal eğilimler oluşturmak; logo ve ambalaj gibi tasarıma ait özellikler ile marka üstünlüğü yaratmak ve diğerlerinden ayırt edilebilir hale getirmek; güven oluşturmak ve satışa engel olan yanlış bilgiyi ortadan kaldırmak da özel amaçlar olarak söylenebilir (Gürgen, 1990, s.8). Günümüzde reklam için kullanılan iletişim mecralarındaki zengin çeşitlilik ile tüketici, basılı reklamlardan dijital ve sanal ortamlara kadar yaşamının her sürecinin içinde reklam yer alarak satın almayı arzulamasını sağlar.

\section{Reklam Türleri}

Reklam türleri ile ilgili çok sayıda sınıflandırılma yapılmıştır. Cook (2001) reklam türlerini radyo, televizyon, gazete ve interneti kapsayan araca göre; günlük ihtiyaçlar, lüks tüketim ürünleri ve sivil toplum kuruluşu, siyasi parti gibi bir ürünü olmayanları kapsayan ürün ve hizmete göre; doğru ve dolaylı anlatım olarak da tekniğe göre üç başlıkta toplamıştır. Yeshin ise reklam türlerini amaca, araca, coğrafyaya ve hedef kitleye göre sınıflandırır (Yeshin, 2006, s.5). Mesaj stratejisi üzerinden yapılan bir diğer reklam türleri sınıflandırmasında ise ürün bilgisi ile imajı, yaşam tarzı ve kişiselleştirme olarak dört başlıkta ele alınmıştır (Richards, vd., 2000, s.36). Bir başka reklam türleri sınıflandırmasında da yapanlara ve amaca, hedef pazara, taşıdığı mesaja, zamana, coğrafi kıstaslara göre ve kullanılan araçlar bakımından ele alınabilir (Mucuk, 1999, s.219).

Reklamı yapanlara göre üreticinin kendi ürünlerini ülke genelinde kitle iletişim araçlarını kullanarak yaptığı reklamlar üretici (genel reklamlar), ürünün sadece üreticinin mağazalarında ya da sınırlı bir bölgede aracı işletmeler 
vasıtası ile yapılan reklamlar aracı (lokal reklamlar) ve banka, sigorta şirketleri gibi kendi hizmetlerini tanıtan reklamlar hizmet işletmesi reklamları olarak üçe ayrılabilir (Kocabaş ve Elden, 1997, s.24). Amaç açısından reklamlar; özellikle yeni ve belirlenen ürün gurubu için talep, satış ile pazar payı artırmaya çalışan reklamlar; belirlenen markaya talep, farkındalık ile bağımlılık artırmaya çalışan reklamlar olarak iki gurupta ele alınabilir (Odabaşı, 1995, s.65). Hedef pazara göre reklamlar, tüketiciye markayı hatıllatan, bağımlılık oluşturan ve satın alma davranışına yönlendiren tüketici reklamlarl; perakende ve toptancı gibi aracılara ürünü tanıtmasına ve satmasına teşvik edici ticari reklamlar; işletmelere yönelik hammadde gibi içerik ve ürün özellikleri hakkında bilgilendirici endüstriyel reklamlar olarak üç farklı başlıkta incelenebilir (Yaylacı; 1999, s.13).

Taşıdığı mesaja göre reklamlar, bir ürünü tüketiciye satacak olanlar için hazırlanan ürün reklamı; ürün sahibi işletmenin adı, kurumsal imajı üzerinde durulan kurumsal reklamlar olarak iki ayrı guruba ayrılır (Tolungüç ve Tanitım, 1999, s.118). Zamana göre reklam, hemen satın alma ve uzun dönemde satın almaya yönlendiren reklamlardır (Kocabaş ve Elden, 1997, s.26). Coğrafi kıstaslara göre reklam, toptancı ya da dağıtımcı tarafından belirli bir bölgede hedeflenen kitle için yapılan bölgesel reklam; ülke genelinde hedeflenen kitle için yapılan ulusal reklam; perakendeci tarafından hedeflenen yerel tüketiciler için yapılan yerel reklam; çok uluslu şirketlerin farklı ülkeleri hedeflediği uluslararası reklam ve tüm insanların ortak duygu ve düşüncelerinden yola çıkarak yapılan global reklamlar olarak beş başlıkta ele alınabilir (Çivrilli, 1993, s.82).

Ürün yerleştirme açısından reklam türleri, para karşılığı yapıldığı açıç̧a belli olan açık reklam; ürünün reklam içerisinde dolaylı olarak bulunduğu gizli reklam ve gizli olmayan, normal reklam sürelerinden daha uzun süren bir dizi halinde tüketiciyi bilgilendiren tanıtıcı reklamlar olarak üç başlıkta ele alınabilir. Kullanılan araç bakımından reklamlar ise radyo, televizyon gibi konvansiyonel medya mecraları; gazete, dergi, el ilanları, katalog gibi basılı ortamlar ve internet ortamları gibi çok çeşitli mecralarda yapılan reklamları içerir (Tokol, 1996, s.142). Bunların yanı sıra fuarlar, açı hava reklam araçları, doğrudan postalama, sinemalar, satıs yeri reklam malzemeleri de kullanılan araçlar bakımından reklam türleridir. 


\section{Sosyal Medya}

Bugün çağın gelişmiş ve yaygın teknolojik gelişmeleri ile reklam sınırsız bir yayın olanağına kavuşmuştur. Bu yayın mecralarının en yaygın olarak kullanılanı ise internet ve sosyal medya ortamları olarak görülür. Milgram'ın küçük dünya (Small World) görüngüsü (fenomen) ile 1967 yılında ilk kez bahsettiği ağ üzerinden bağlantı kurarak iletişime geçme fikrini (Onat ve Alikılıç, 2008), Truscott ve Ellis' in 1979 yılında ortaya attı̆ 1 sosyal medya kavramından bahsederlerken, internet kullanıcılarının tüm dünya genelinde ileti yollama olanağı üzerinde durmaları ile devam etmiştir. Günümüzdeki anlamı ile kullanımı ise internet üzerinden günlük yazıların yazılabildiği ve bunların bir platformda toplandığı sosyal ağ (web sitesi) kuran Bruce ve Susan Abelson ile başlamıştır (Kaplan ve Haenlein, 2010). Open Diary ismini verdikleri bu sosyal paylaşım sitesi dünyada bir ilk olarak nitelendirilirken, teknolojideki hızlı gelişmelere bağlı olarak internetin yayılması, erişiminin kolaylaşması ve herkes tarafından kullanılması ile bugün de kullanılan sosyal medya olarak ifade edilmeye başlanmıştır. Bir ağ üzerinden birbiriyle iletişime geçen kullanıcıların, çeşitli paylaşım, yorum ve aktivitelerde bulunması olarak ifade edilen sosyal medya için (Kirtiş ve Karahan, 2011) bir başka tanımda; karş1lıklı etkileşim içerisine giren kullanıcıların her türlü yazılı veri, ses, görsel ve hareketli görüntü paylaşabildikleri medya ortamları olarak ifade edilir (Sayımer, 2009).

Sosyal medyanın temel amacı olarak; insanlar arasındaki etkileşimi sağlamak ve bu sayede yeni sosyal yapılar ve iş pratiklerinin hedeflendiği belirtilir (İyiler, 2009). Sosyal medyanın, konvansiyonel medyaya göre daha çok bilgi aktarımı sağlayan bir mecra olduğu düşünülürken (Li, vd., 2002, s.38), pazarlama iletişimi açısından ise diğer reklam ortamlarına göre benzersiz özelliklere sahip olduğu görüşü yaygındır (Faber, vd., 2004). Konvansiyonel medya ortamlarında yer alan reklamlar ürün, hizmet ya da marka ile ilgili sınırlı bilgiyi tüketiciye aktarabilirken; internette yer alan sosyal medya mecralarında rakip markalar, ürün özelliklerine ait bilgiler ve daha fazlası da aynı anda sunulmakta ve bu durum tüketicinin kıyaslama yaparak satın alma davranışı sırasındaki kararlarına etki edebilmektedir. Bu noktada kullanıcılar bir ağ üzerinden istedikleri ürün, hizmet ve bilgiye istedikleri zaman ulaşabilir; sosyal medya mecraları ile tüketici forumları, anket ve kişisel ya da gurup blog- 
ları ile satın alma davranışı gösterdikleri konu ile ilgili sınırsız çeşitli veri toplayarak değerlendirebilirler. Kullanıcıların bir ağ ile satın alma davranışı gösterdikleri ürün ve hizmet ile alakalı bilgi arayışı, bilişim çağının en gözde aktivitesi olarak değerlendirilmekte (Choi, vd., 2003, s.32), bu sebeple de ağ üzerinden sosyal medya mecraları ve bu mecralarda var olan reklamlar ile tüketime çekildiği ifade edilmektedir (Shim, vd., 2000, s.37). Özellikle günümüz bilişim çağında gençler için bir sosyalleşme ortamı sağlayan sosyal medya, metin, fotoğraf, video ve müzik gibi verilere kolay erişilebilir olma, veriyi depolama, paylaşma ve yayma özelliği ile hayatın her alanında yer almaktadır.

\section{Sosyal Medya Reklamlar}

İlk kez Hotwired dergisinin 1994 yılında yapmış olduğu reklam bantı ile başlayan ağ üzerinden reklam, bulunduğu dönem içerisinde büyük başarı yakalamış (Kaye ve Medoff, 2001, s.5), sonraki dönemler için ağ üzerinden sosyal medya reklam türü olarak pazarda yer bulmuştur. Konvansiyonel reklamlardaki gibi ürün ya da hizmetin bilinirliğini artırmak, ürün ya da hizmetin faydalarına ait kazanım geliştirme ve ilgi çekmek gibi tüm karakteristik özelliklerini taşıyan sosyal medya reklamlarında da tüketiciyi satın alma davranışında bulunmaya yönlendirmek için söz, müzik, yazı, hareketli grafikler ve video gibi çeşitli ögelere ihtiyaç duyar (Lance ve Woll, 2006, s.258). Üretici ve tüketiciyi bir ağ üzerinde buluşturan her türlü bilgi, online pazarlama olarak ifade edilen sosyal medya reklamlarının konvansiyonel reklamlara göre en belirgin farkı etkileşim özelliği göstermesi (Kırcova, 2005), bilginin zengin görsellik ile sunulması ve ürün ya da hizmete doğrudan ulaşma imkanı sunmasıdır (Korgaonkar ve Wolin, 2002).

Sosyal medya reklamları video, ses ya da yazı gibi farklı biçimlerde ya da elektronik posta, oyun, logo ve reklam bandı gibi farklı kanallarla tüketiciye verilebilir (Schlosser, vd., 1999) olması bakımından reklam bağlamında önemli bir yere sahiptir. Teknolojideki gelişmeler ile bir ağ üzerinden bilgiye ulaşma ve iletişim kurma gibi davranışlar değişerek, her yaşa ve hayatın her alanına etki edecek konuma dönüşmüştür. Bununla birlikte pazarlama mecralarını da etkileyerek tüketicilerin satın alma davranışlarında sosyal medya pazarlama alanı, pazaryeri olarak yer almaya başlamıştır (Jerome, vd., 2010). Sosyal medya ortamları yalnızca tüketici açısından değil, ürün ve hizmet, marka ve işletmeler için de en çok kullanılan, tercih edilen, önem verilen ve 
farkındalık oluşturabilecekleri bir mecra olmuştur. Reklamların sosyal medya ortamlarında sayfa içerisinde görüntülenmelerinin dışında, etkileşim içerisinde oldukları diğer kullanıcıların reklamı yapılan ürün, hizmet ya da markaya ait beğeni ve yorumlarını görmeleri ile güven hissi ve buna bağlı olarak satın alma davranışı ortaya çıar (Chan, 2011). Bu güven hissi aynı zamanda sosyal medya reklamlarının çok kısa sürede yayılmasına da olanak sağlar.

2019 y1lu internet ve sosyal medya verileri We Are Social ve Hootsuite tarafından 2019 yılı 4. Çeyrek raporu olarak tüm dünya ile paylaşılmıştır. Raporda 'Digital 2019 in Turkey' başlığı altında yer alan araştırmada (Şekil 1), 82,4 milyon nüfusa sahip olan Türkiye'de nüfusun $\% 72$ 'sinin internet kullandığıi; \%63'ünün aktif olarak sosyal medya kullandığı ve \%53'ünün de mobil hatlar üzerinden sosyal medya kullandığı yer almıştır (Şekil 1).

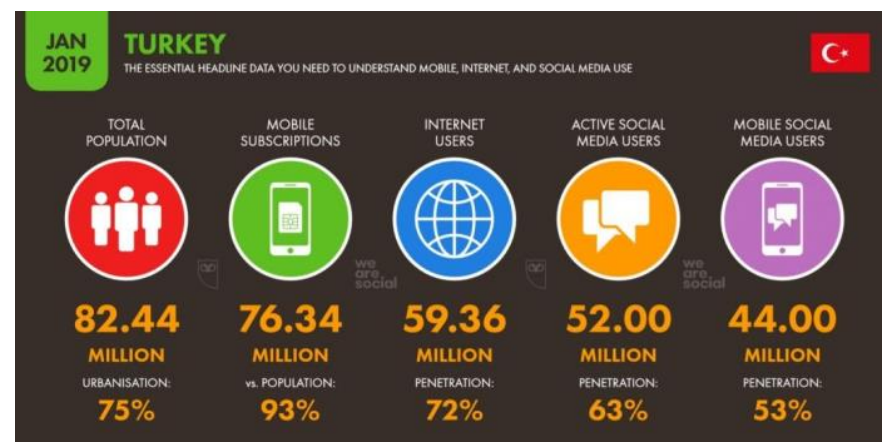

Şekil 1. Digital 2019 in Turkey. (Dijilopedi, t.y)

Araştırmada yer alan verilere göre (Şekil 2), 2019 yılında Türkiye nüfusunun $\% 99^{\prime}$ u televizyon sahibi iken, \%98'i taşınabilir bir telefona sahip olup bunların \%77'sini ise akıllı telefonlar oluşturmaktadır. Aynı verilere göre masaüstü ve dizüstü bilgisayar kullanıcı oranı $\% 48$, tablet kullanıcı oranı $\% 25$ ve giyilebilir teknoloji ürünü kullanıcı oranı ise $\% 9$ olarak açıklanmıştır. 


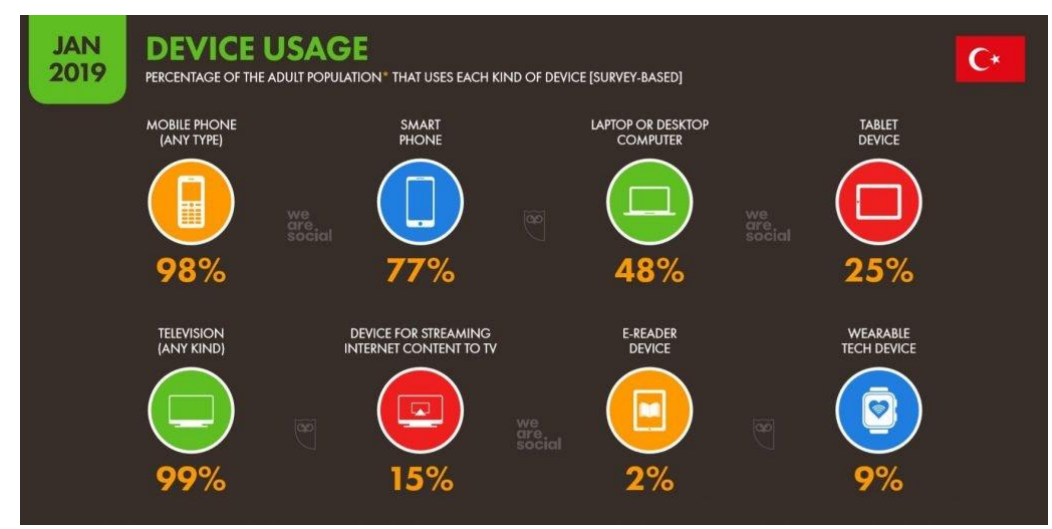

Şekil 2. Elektronik cihaz kullanımı verileri. (Kaynak: dijilopedi, t.y)

'Digital 2019 in Turkey' başlığı altında yer alan verilere göre (Şekil 3.) Türkiye'de internet kullanımı günlük ortalama 7 saat 15 dakika olarak açıklanmiştır. Bu sürenin ortalama 2 saat 46 dakikası Instagram, Facebook, Twitter, LinkedIn vb. sosyal medya ortamlarında geçirildiği, 3 saat 9 dakika internet üzerinden canlı yayın yapan televizyon kanalları, Netflix vb. izlendiği ve 1 saat 15 dakika da internet üzerinden müzik dinlendiği yapılan araştırma ile ortaya konmuştur. İlk kez 2019 yılı raporunda yer alan cinsiyet dağılımına göre Türkiye sosyal medya kullanım oranlarında, 43 milyon kayıtlı kullanıcısı olan Facebook ve 38 milyon kayıtlı kullanıcı olan Instagram sosyal medya mecralarının erkek kullanıcı sayısı, kadın kullanıcılara göre daha fazla olduğu açıklanmıştır. Benzer şekilde 9 milyon kayıtlı kullanıcıya sahip Twitter sosyal medya mecrasını kullanan her 10 kişiden 8'i erkek olarak ve 7,3 milyonluk kayıtlı kullanıcıya sahip LinkedIn ise yine en çok erkekler tarafından kullanıldığı; 6,3 milyon kayıtlı kullanıcı olan Snapchat' in ise en çok kadınlar tarafından tercih edildiği raporda yayınlanmıştır. 


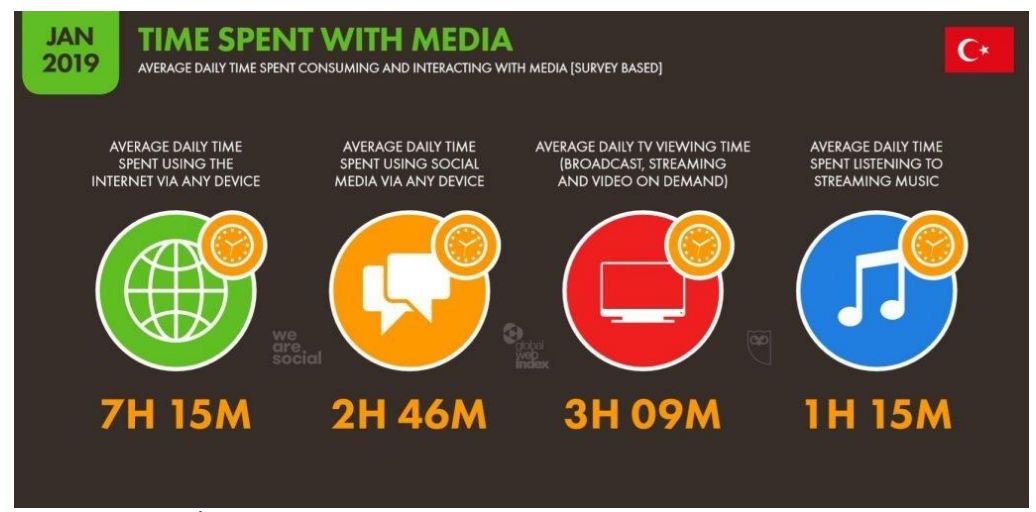

Şekil 3. Internette vakit geçirme oranları. (Kaynak: dijilopedi, t.y)

\section{Araştırma Yöntemi}

442 adet katılımcıdan elde edilmiş olan; 10 adet soruya sahip soru formu vasıtasıyla toplanan birincil veriler; SPSS programı ile analiz edilmiş ve Sayısal Tablo Programından da yararlanılmıştır. Ölçek ifadeleri Likert-5 düzeyinde (hiçbir zaman-bazen-fikrim yok-genellikle-her zaman) olup ayrıca kategorik soruları da içermektedir. Ölçek sorularına ait güvenirlik katsayısı (Cronbach's Alpha) 0,690 olarak bulunmuştur. Dolayısıyla araştırmada kullanılan ölçeğin güvenirliği konusunda yeterli düzeyde olduğu kanısına varılmıştır. Faktör analizi sonucunda KMO değeri 0,77; Barlett test p değeri 0,000 olarak hesaplanmış ayrıca modelin açıklama oranı \%55,127 ve tüm ifadelere ilişkin öz değerlerin ise 0,50 den büyük oldukları gözlemlenmiştir. Dolayısı ile ölçeğin geçerlilik ve güvenilirlik düzeylerinin uygun seviyede oldukları kanaatine ulaşılmıştır.

\section{Araştırma Bulguları}

442 katılımcı ile yapılan araştırmada katılımcılara ilişkin bilgiler; \%44,6 oranı 21-30 yaş; \%27,1 20 yaş ve altı olup en düşük oran \%0,9 ile 61 yaş ve üstü yaş aralığında yer almaktadır. Cinsiyete göre dağılım yaklaşık olarak eşit olup (217 kadın, 225 erkek) medeni durumları \%79 oranında bekar durumundadırlar. Katılımcıların büyük oranı üniversite öğrencilerinden oluşmakta ve \%57,2 oranı öğrenci; \%22,9 çalışan, \%14,9 oranı ise çalışan öğrenci niteliğini taşımaktadırlar. En düşük katılımcı oranı \%5 ile emekliler tarafından teşkil edilmiştir. 
Araştırma bulgularına göre, reklamların alışveriş kararlarını etkilemesi: \%58,4 oranında "bazen"; \%17,9 oranında "genellikle"; \%5,9 oranında "her zaman"; \%14,3 oranında "hiçbir zaman" etkilemektedir.

"Sosyal medyada belirli bir sürede zorunlu olarak izlettirilen reklamların akılınızda kalıcılığı nasıldır?" Sorusuna verilen cevapların dağılımı; \%38,9 oranında "bazen"; \%22,2 oranında "genellikle"; \%4,5 oranında "her zaman"; \%26,9 oranında "hiçbir zaman" biçiminde gerçekleşmiştir.

"Sosyal medyada zorunlu olarak izlettirilen reklamlardan ne derecede yararlanıyorsunuz?" Sorusuna verilen cevapların dağılımı; \%36,9 oranında "bazen"; \%7,0 oranında "genellikle"; \%3,4 oranunda "her zaman"; \%44,1 oranında "hiçbir zaman" biçiminde gerçekleşmiştir (Şekil 4).

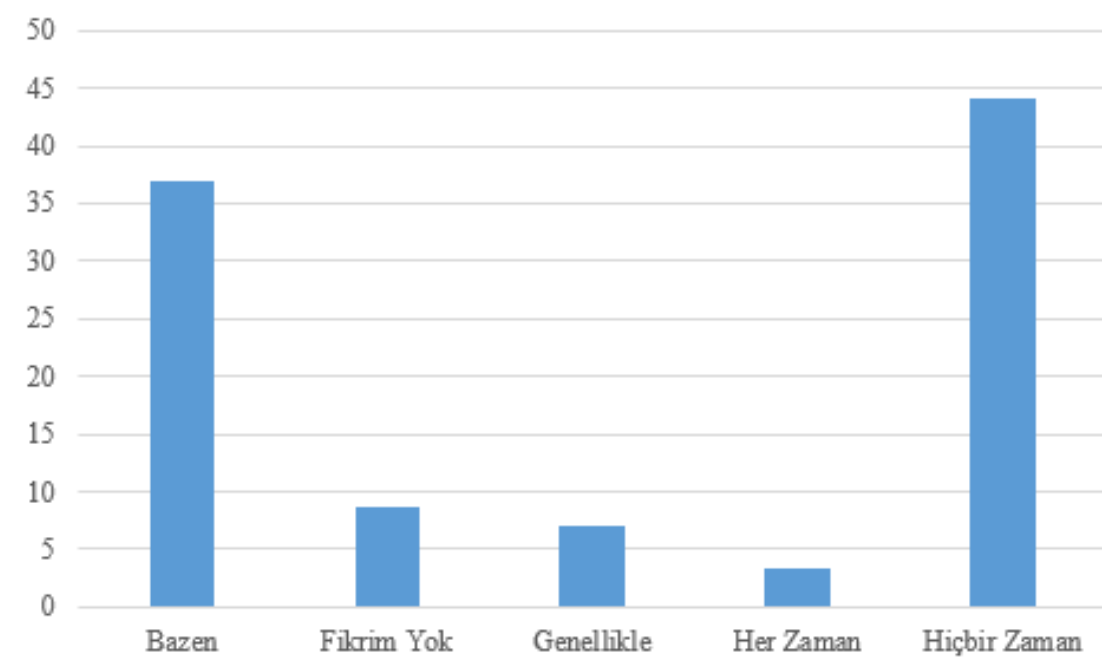

Şekil 4. Sosyal medyada zorunlu izlenen reklamlarn yararlılk oranları.

"Reklamları gerçekçi buluyor musunuz?" Sorusuna verilen cevapların dağılımı; \%46,4 oranında "bazen"; \%10,2 oranında "genellikle"; \%1,4 oranında "her zaman"; \%33,7 oranında "hiçbir zaman" biçiminde gerçekleşmiştir (Şekil 5). 


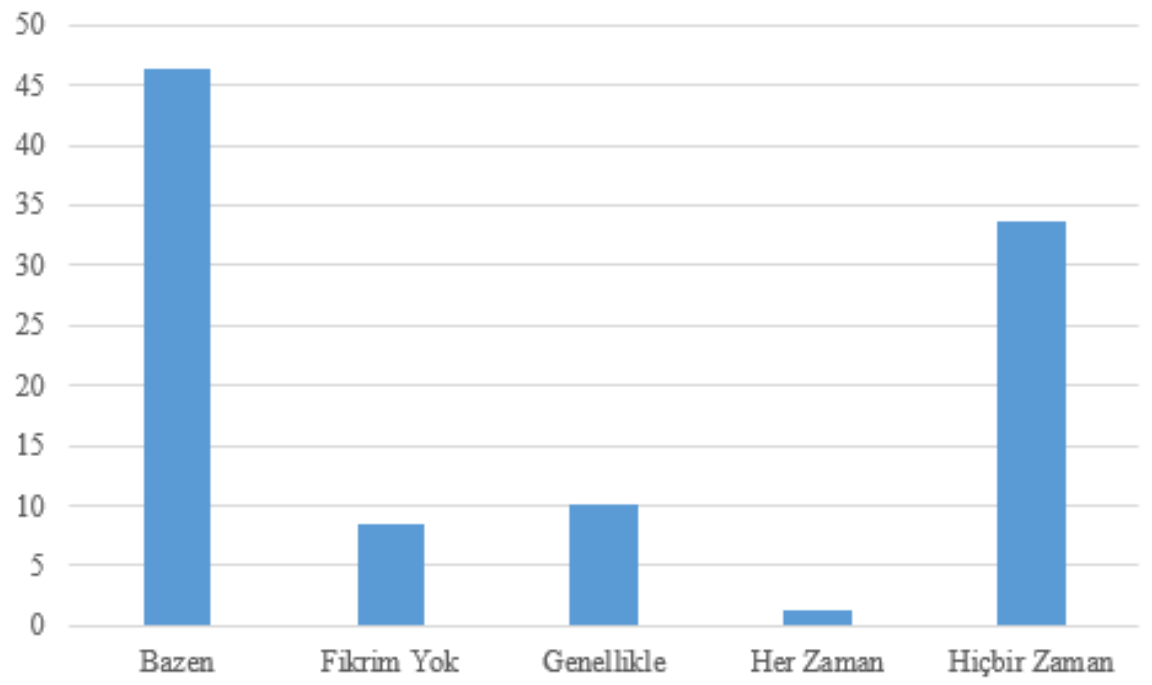

Şekil 5. Sosyal medyadaki reklamlarn gerçekçi bulunma oranları.

“Bir yakınınıza, görmesini tavsiye ettiğiniz herhangi bir reklam çalışması oldu mu?" sorusuna verilen cevapların dağılımı; \%33,0 oranında "bazen"; \%10,2 oranında "genellikle"; \%6,3 oranında "her zaman"; \%43,2 oranında "hiçbir zaman" biçiminde gerçekleşmiştir (Şekil 6).

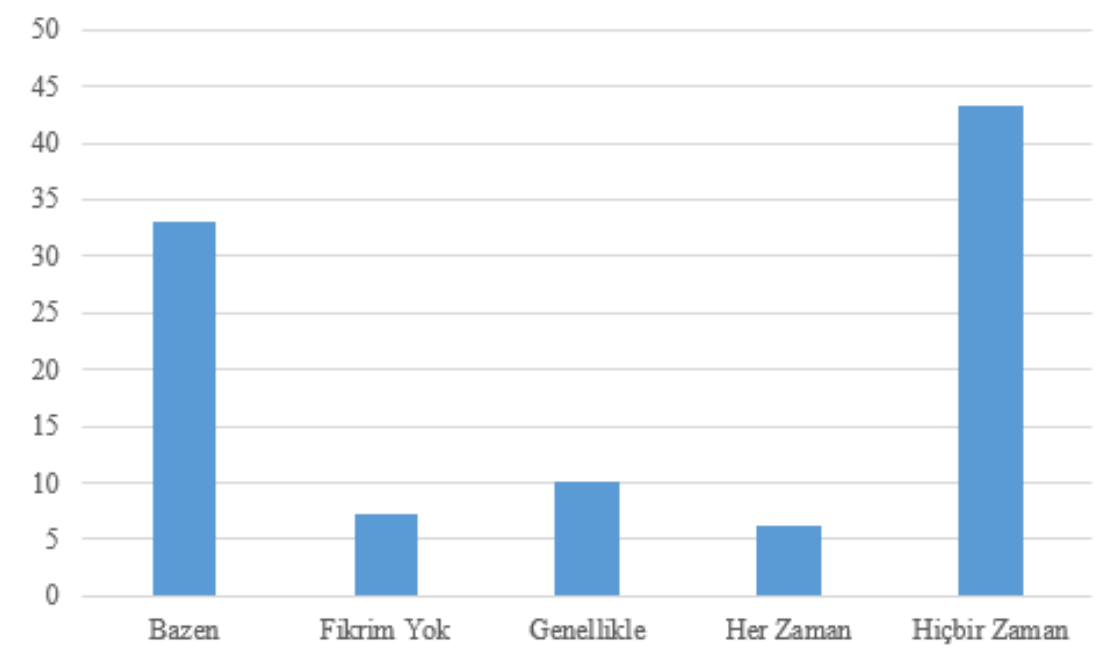

Şekil 6. Sosyal medyadaki reklamlarda iletilenin başkasına tavsiye edilme oranları. 
"En çok ilgilendiğiniz reklam türü incelendiğinde, Giyim ve teknoloji ilk sıralarda yer alırken, politik ve ulaşım hususlarının ise en düşük skora sahip oldukları gözlemlenmiştir (Şekil 7).

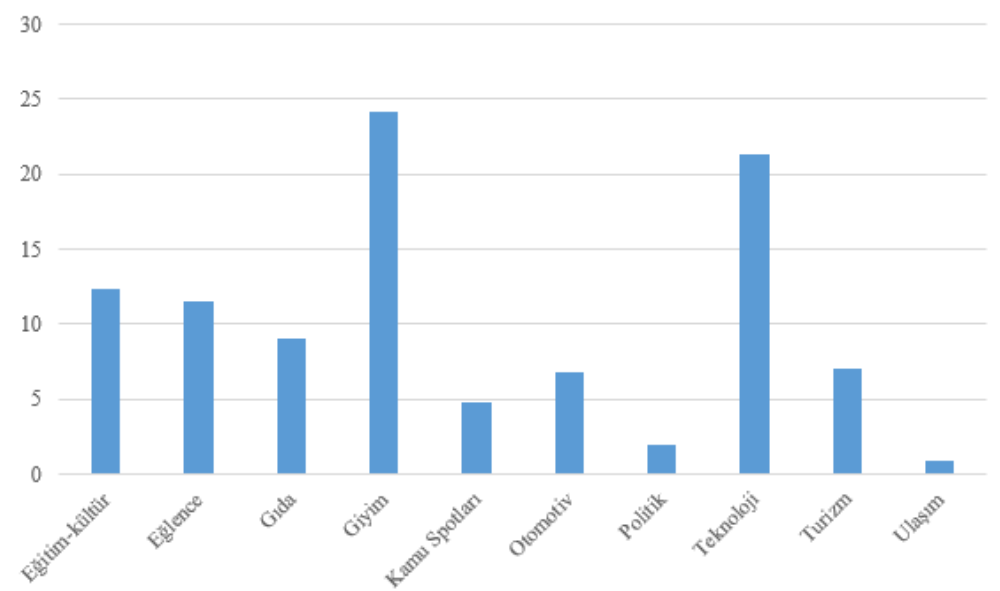

Şekil 7. Sosyal medyadaki reklamlarnn ilgi çekme oranları.

Reklamların kişilere ulaşım yolları bakımından en etkili reklam mecrasının sosyal medya, en düşük skorlu reklam ulaşım kanalının ise doğrudan (Broşür-vitrin-ürün ambalajı) reklam mecraları olduğu gözlemlenmiştir (Şekil 8).

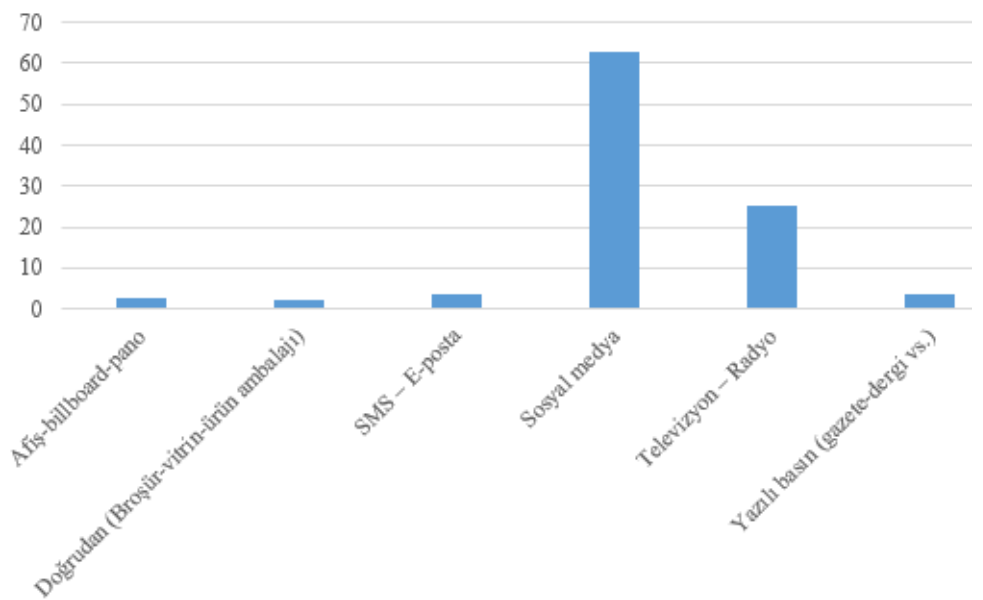

Şekil 8. Çeşitli reklam mecralarnın ilgi çekme oranlarn. 
Kişilerin en çok etkilendiklerini düşündükleri reklamların yayınlandığ kanallar itibari ile en etkileyici reklam mecrası, sosyal medya olarak öne çkarken, en düşük etkinlik SMS-e-posta yoluyla yapılan reklamların olduğu görülmektedir (Şekil 9).

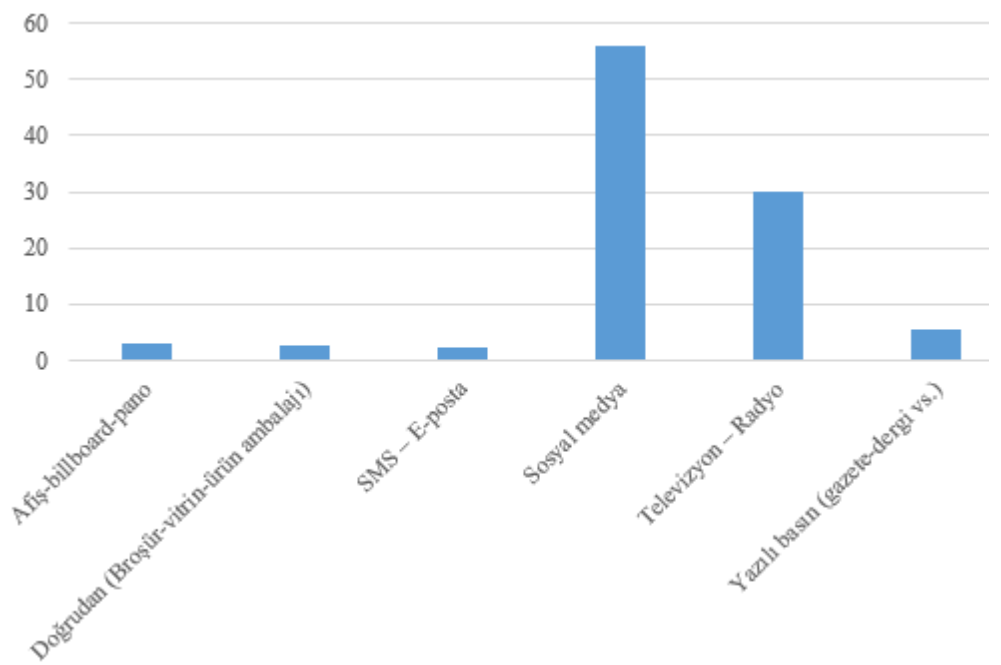

Şekil 9. İlgi çeken reklamların mecra dağılımı oranları.

Kişiler, sosyal medya ortamında zorunlu olarak izlemek zorunda kaldıkları reklamlarla karşılaştıklarında; \%31,4 oranında "sinirlenirim", \%30,5 oranında ise "hoşlanmam" cevabı verilmiştir. "İlgi ile izleme" ise \%3,2 oranına sahiptir (Şekil 10).

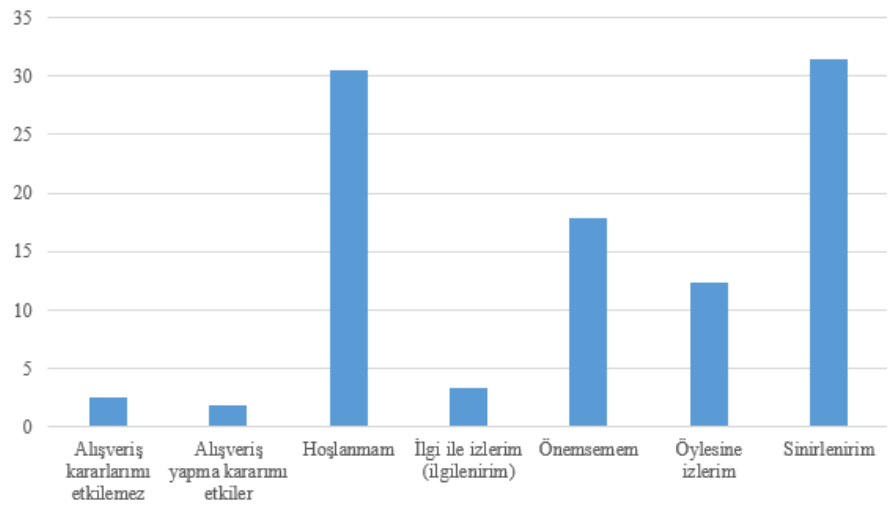

Şekil 10. Sosyal medyada zorunlu izlenen reklamlarn yarattığı tepkiler ve oranlar. 
Kişileri en az etkileyen reklam mecralarının dağılımı incelendiğinde (etkisizlik oranları); SMS-E-posta ve sosyal medya mecralarının en az etkileyicilikte, bir başka ifade ile en yüksek etkisizlikte oldukları, afiş-billboard-pano mecralarının ise nispeten daha yüksek etkileyiciliğe sahip oldukları gözlemlenmiştir (Şekil 11).

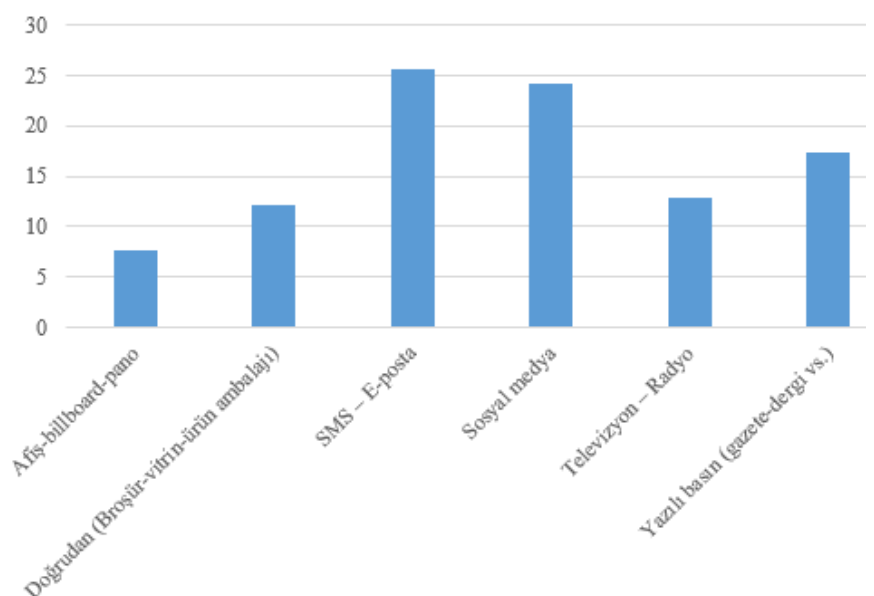

Şekil 11. Reklam mecralarnnn etkisizlik oranlarn.

\section{Demografik Niteliklere Göre Reklam Algılan}

Yaş: Yaş itibari ile reklamların alı̧veriş kararına etkisi; \%75 "bazen" 61 ve üstü yaş grubu için en yüksek değer, 41-50 yaş grubu için \%72 ile "bazen" ikincil değer olarak sıralanmıştır. Ayrıca, 31-40 yaş grubu için \%11 oranında "her zaman" ve \%19 oranında "genellikle" seçenekleri belirgin olarak öne çıkmaktadır.

Sosyal medyada belirli bir sürede zorunlu olarak izlettirilen reklamların "aklınızda kalıcılığına" dair algı; tüm yaş grupları için ağırlıklı olarak "bazen" biçiminde değerlendirilmiştir. Ancak 20 ve altı yaş grubundan alınan "her zaman" cevabı en yüksek oranda olup yaş grubu ilerledikçe bu cevap oranı giderek azalmaktadır (\%28-\%23-\%22-\%12-\%4- \%0).

Zorunlu sosyal medya reklamlarından yararlanma algisı; 61 ve üstü yaş grubunda \%75 oranında "hiçbir zaman" olmakla beraber 31-40 yaş grubu hariç (\%42-Bazen) diğer hepsi için ağırlıklı görüş durumundadır. 
Reklamların gerçekçiliği hususundaki algılama itibari ile 51-60 yaş grubu hariç (\%54-hiçbir zaman) hepsinde "bazen" ağırlıklı cevap durumundadır. Reklamların gerçekliğine ilişkin en yüksek algı 20 ve altı yaş grubunda gözlemlenmiştir (\%15 genellikle; \%3 her zaman). 51-60 yaş grubu ise gerçekliğe ilişkin en düşük puana sahiptir (genellikle ve her zaman seçenekleri; \%0).

Reklamları tavsiye etme eğilimi en yüksek olarak 61 ve üstü yaş grubunda (\%25-genellkile), 20 ve altı yaş grubunda (\%15-genellikle) ve 21-30 yaş grubunda (\%11-genellikle) gözlemlenmiştir. 41-50 yaş grubu ise tavsiye eğilimi en düşük orana sahiptir.

Yaş grubuna göre ilgilenilen reklam türleri: 20 ve altı yaş grubu için en fazla giyim (\%28) ve eğlence (\%20), en az ise ulaşım (\%0), politik ve kamu spotları (\%2) reklamları teşkil etmektedir. 21-30 yaş grubunda en fazla ilgiyi giyim (\%25) ve teknoloji (\%23) reklamları çekerken en az ilgi gösterilen reklam türleri ulaşım (\%1) ve politik (\%2) türlerdir. 31-40 yaş grubunda en yüksek ilgiyi teknoloji (\%30) ve giyim (\%20) türü reklamlar oluştururken en düşük ilgiyi eğlence $(\% 0)$ ve ulaşım (\%0) ile ilgili reklamlar oluşturmaktadır. 4150 yaş grubunda giyim (\%23) ve turizm (\%19) en yüksek; politik (\%0) türler ise en düşük ilgi gösterilen reklam türlerdir. 51-60 yaş aralığında; en yüksek ilgi eğitim-kültür (\%17) ve teknoloji (\%17) hususlarında görülürken en düşük ilgi eğlence (\%0) ve ulaşım (\%0) reklamlarında gözlemlenmiştir. 61 ve üstü yaş grubunda açık ara ile gıda (\%50) ilgiyi çekerken eğitim-kültür (\%25) ve teknoloji (\%25) ile ilgili reklamlar onu takip etmektedir. Diğer reklam türlerinin bu yaş grubu için ilgi çekici durumda olmadığ gözlemlenmiştir.

Reklamların alınma mecraları: 20 ve altı yaş grubu için reklamların en fazla alındığı mecra sosyal medya (\%71) ve televizyon-radyo (\%19), en düşük etkili mecra ise yazılı basın (gazete-dergi vs.) (\%2) ve doğrudan (broşür-vitrin-ürün ambalajı) (\%2) reklam mecraları olarak gözlemlenmiştir. 21-30 yaş grubunda en etkili mecralar sosyal medya (\%65) ve televizyon-radyo (\%21) iken en düşük orana sahip olanlar ise doğrudan (broşür-vitrin-ürün ambalajı) (\%2) ve SMS-E-posta (\%3) reklam mecraları tarafından teşkil edilmektedir. 31-40 yaş aralığ için en etkili mecralar sosyal medya (\%54) ve televizyonradyo (\%11) iken en düşük orana sahip olanlar ise yazılı basın (gazete-dergi vs.) (\%2) ve afiş-billboard-pano (\%2) mecralarıdır. 41-50 yaş grubu için en etkili mecralar sosyal medya (\%56) ve televizyon-radyo (\%40) iken en düşük orana sahip olanlar ise yazılı basın (gazete-dergi vs.) (\%0) ve doğrudan (bro- 
şür-vitrin-ürün ambalajı) $(\% 0)$ reklam mecralarıdır. 51-60 yaş aralığı, diğerlerinden farklı olarak en yüksek olarak televizyon-radyo (\%75) ve SMS-E-posta (\%25) olurken diğer reklam mecralarına ilgi gösterilmediği gözlemlenmiştir.

Kişilerin en çok etkilendiği reklam mecraları incelendiğinde: 20 ve altı yaş grubunda en çok etkileyen reklam mecrası sosyal medya (\%68), en az etkileyen ise afiş-billboard-pano (\%2); 21-30 için sosyal medya (\%60) en yüksek, doğrudan (broşür-vitrin-ürün ambalajı) (\%3) ve SMS- E-posta (\%3) en düşük orana sahiptir. 31-40 için en yüksek televizyon-radyo (\%44), SMS- E-posta $(\% 0)$ ise en düşük etkiye sahiptir. 41-50 yaş aralığ için sosyal medya ve televizyon-radyo eşit ağırlıkla (\%42) en etkili reklam mecraları olurken en düşük etki doğrudan (\%0) reklam mecralarınca oluşturmaktadır. 61 ve üstü yaş aralığ için en etkileyici reklam türü televizyon-radyo (\%100) olurken, diğerler reklam mecralarının bu yaş aralığında etkinlik sağlayamadığı gözlemlenmiştir. Tüm yaş grupları dikkate alındığında en etkili reklam mecralarının sosyal medya (\%56), en düşük etkileyici mecraların ise SMS- E-posta (\%2) olduğu ifade edilebilir.

Sosyal medyada zorunlu olarak izlettirilen reklamlar karşısında sergilenen davranışların yaş gruplarına göre dağılımı: 20 ve altı sinirlenirim (\%26) ve hoşlanmam (\%26), ilgi ile izlerim (ilgilenirim) (\%3) ve alışveriş kararlarımı etkilemez (\%3); 21-30 için hoşlanmam (\%36), alışveriş yapma kararımı etkiler (\%1); 31-40 için sinirlenirim (\%39); 41-50 için sinirlenirim (\%37); 51-60 için sinirlenirim (\%58) ve 61 ve üstü için sinirlenirim (\%50) olarak gözlemlenmiştir. Genel olarak zorunlu sosyal medya reklamlarının sinirlenmeye (\%31) ve hoşlanmamaya (\%31) sebep olduğu ifade edilebilir.

En az etki oluşturan reklamların yayınlandığı kanalların incelenmesi: 20 ve altı yaş grubunda sosyal medya (\%24) ve SMS-E-posta (\%23); 21-30 için sosyal medya (\%25) ve SMS-E-posta (\%25); 31-40 için SMS-E-posta (\%39); 4150 için SMS-E-posta (\%26); 51-60 için sosyal medya (\%38); 61 ve üstü yaş grubu için ise SMS-E-posta (\%50) ve afiş-billboard-pano (\%50) olarak gözlemlenmiştir. Genel olarak SMS-E-posta (\%26) ve sosyal medya (\%24) en az etki oluşturan reklam mecraları olarak öne çıkmaktadırlar.

Cinsiyet: Cinsiyet itibari ile hem kadın (\%59) hem de erkek (\%58) tüketiciler reklamların "bazen" düzeyinde alışveriş kararlarını etkilediği gözlemlenmiştir ancak kadınlar hiçbir zaman (\%15) cevabı erkeklere (\%13) nazaran daha yüksek seviyede çıkmaktadır. 
Sosyal medya zorunlu reklamlarının akılda kalıcılığına ilişkin algılama, kadın ve erkekler için hemen hemen aynı sonuçları göstermektedir (kadın ve erkek \%39-bazen; \%28 kadın/\%26 erkek-hiçbir zaman).

Zorunlu sosyal medyadan yararlanma algısına bakıldığında: kadın \%47/erkek \%41-hiçbir zaman; kadın \%35/erkek \%38-bazen; kadın \%3/erkek \%5-bazen. Reklamların gerçekçiliğine ilişkin; kadınlar \%45, erkekler \%48 oranında bazen; kadınlar \%37, erkekler \%30 oranında hiçbir zaman olarak değerlendirmişlerdir.

Reklam tavsiyesi konusunda kadınlar \%42, erkekler \%44 oranında hiçbir zaman; $\% 35 / \% 3$ bazen olarak görüş bildirmişlerdir.

Cinsiyetlere göre en çok ilgi çeken reklamlar: Kadınlar; giyim (\%39)-eğitim-kültür (\%12)- teknoloji (\%11)-gıda (\%10)-eğlence ve turizm (\%9)-kamu spotları (\%6)- politik (\%2)- ulaşım ve otomotiv (\%1). Erkekler; teknoloji (\%32)eğlence (\%14)- eğitim-kültür (\%13)- otomotiv (\%12)- giyim (\%10)- gıda (\%8)turizm (\%5)- kamu spotları (\%3)- politik (\%2)- ulaşım (\%1).

Reklamların en çok alındığı mecra itibari ile kadınlar ve erkekler benzer tercihlere sahiptirler [Kadın: sosyal medya (\%63) ve televizyon-radyo (\%24); erkek: sosyal medya (\%63) ve televizyon-radyo (\%27)].

En çok etkileyen reklam mecraları kadınlar için sosyal medya (\%52) ve televizyon-radyo (\%32); erkekler için sosyal medya (\%60) ve televizyon-radyo (\%28) biçiminde sıralanmaktadır. En az etkileyen reklam mecraları ise kadınlar için afiş-billboard-pano (\%3) ve SMS- E-posta (\%3); erkekler için ise SMSE-posta (\%2) ve doğrudan (broşür-vitrin-ürün ambalajı) (\%1).

Sosyal medya zorunlu reklamları karşısında sergilenen davranışlara göre: Kadınlar; hoşlanmam (\%31)-sinirlenirim (\%29)-önemsemem (\%19)-öylesine izlerim (\%14)-ilgi ile izlerim (ilgilenirim) (\%3)-alışveriş kararlarımı etkilemez (\%2)-alışveriş yapma kararımı etkiler (\%1). Erkekler; sinirlenirim (\%33)-hoşlanmam (\%30)-önemsemem (\%16)-öylesine izlerim (\%11)-ilgi ile izlerim (ilgilenirim) (\%4)-alışveriş yapma kararımı etkiler (\%3) ve alışveriş kararlarımı etkilemez (\%3).

En az etkilenen reklam mecraları kadınlar için sosyal medya (\%25)-SMSE-posta (\%24)-yazılı basın (gazete-dergi vs.) (\%21). Erkekler için ise SMS-Eposta (\%27)-sosyal medya (\%23)-doğrudan (broşür-vitrin-ürün ambalajı) (\%15)-televizyon-radyo (\%14) ve yazılı basin (gazete-dergi vs.) (\%14). 
Medeni Durum: Reklamların alışveriş kararlarını etkileme oranı: Bekar; bazen (\%57)-genellikle (\%19)-hiçbir zaman (\%14). Evli; bazen (\%63)-hiçbir zaman (\%14) ve genellikle (\%14).

Sosyal medya zorunlu reklamlarının akılda kalıcılığına ilişkin algılar: Bekar; bazen (\%37)-hiçbir zaman (\%26)-genellikle (\%24). Evli; bazen (\%46)-hiçbir zaman (\%30)- genellikle (\%14).

Zorunlu sosyal medya reklamlarından faydalanma algısı: Bekar; hiçbir zaman (\%44)-bazen (\%35). Evli; hiçbir zaman (\%44)-bazen (\%44).

Reklamları gerçekçi bulma konusundaki kanaatler: Bekar; bazen (\%44)hiçbir zaman (\%34)-her zaman (\%2). Evli; bazen (\%54)-hiçbir zaman (\%34)her zaman $(\% 0)$.

Bir başkasına reklam tavsiye etme oranları: Bekar; hiçbir zaman (\%43)-bazen (\%31). Evli; hiçbir zaman (\%45)-bazen (\%41).

En çok ilgilenilen reklam türü dağılımları: Bekar; giyim (\%26)-teknoloji (\%21)- eğlence (\%14)-eğitim-kültür (\%12)-gida (\%9)-turizm (\%7)-otomotiv (\%6). Evli; teknoloji (\%23)-giyim (\%17)-eğitim-kültür (\%13)-kamu spotları (\%12)-otomotiv (\%11)-gida ve turizm (\%9).

Reklamların en fazla alındığı mecralar: Bekar; sosyal medya (\%66)-televizyon-radyo (\%22)-SMS-E-posta (\%4)-yazılı basın (gazete-dergi vs.) (\%3)-afişbillboard-pano (\%2)- doğrudan (broşür-vitrin-ürün ambalajı) (\%2). Evli; sosyal medya (\%51)-televizyon-radyo (\%38)-yazılı basin (gazete-dergi vs.) (\%4)doğrudan (broşür-vitrin-ürün ambalajı) ve SMS-E-posta (\%3)-afiş-billboardpano $(\% 1)$.

En çok etkilenilen reklam mecraları: Bekar; sosyal medya (\%62)-televizyon-radyo (\%25). Evli; televizyon-radyo (\%51)- sosyal medya (\%35).

Zorunlu sosyal medya reklamları karşısında: Bekar; hoşlanmam (\%32)-sinirlenirim (\%30)-önemsemem (\%19)-öylesine izlerim (\%12)-ilgi ile izlerim (ilgilenirim) (\%3). Evli; sinirlenirim (\%38)-hoşlanmam (\%24)-önemsemem (\%15)-öylesine izlerim (\%15)-ilgi ile izlerim (ilgilenirim) (\%3) ve alışveriş kararlarımı etkilemez (\%3).

En az etkilenilen reklam mecraları: Bekar; Sosyal medya (\%25)-SMS-Eposta (\%24)- Yazılı basin (gazete-dergi vs.) (\%17). Evli; SMS-E-posta (\%30)Sosyal medya (\%20)- Televizyon-Radyo (\%17). 


\section{Sosyal Statü Durumu}

Sosyal statü durumuna göre reklamın alışveriş kararına etkisi: Çalışan; bazen (\%66)-genellikle (\%14)-hiçbir zaman (\%12)-her zaman (\%7). Çalışan öğrenci; bazen (\%58)-genellikle (\%21)- hiçbir zaman (\%12)-her zaman (\%8). Emekli; bazen (\%55)-hiçbir zaman (\%27)-genellikle (\%4). Öğrenci; bazen (\%56)-genellikle (\%20)-hiçbir zaman (\%15)-her zaman (\%6).

Zorunlu sosyal medya reklamlarının akılda kalıcılığı: Çalışan; bazen (\%49)-hiçbir zaman (\%33)-genellikle (\%11). Çalışan öğrenci; bazen (\%36)-genellikle (\%29)-hiçbir zaman (\%24). Emekli; bazen (\%50)-hiçbir zaman (\%41)genellikle (\%5). Öğrenci; bazen (\%35)- genellikle (\%26)-hiçbir zaman (\%24).

Zorunlu sosyal medya reklamlarının yararlılığına ilişkin: Çalışan; bazen (\%47)-hiçbir zaman (\%45). Çalışan öğrenci; bazen ve hiçbir zaman (\%41). Emekli; hiçbir zaman (\%77)-bazen (\%23). Öğrenci; hiçbir zaman (\%42)-bazen (\%33).

Reklamların gerçekçiliğine ilişkin görüşler: Çalışan; bazen (\%50)-hiçbir zaman (\%31). Çalışan öğrenci; bazen (\%48)-hiçbir zaman (\%39). Emekli; hiçbir zaman (\%59)-bazen (\%32). Öğrenci; bazen (\%45)-hiçbir zaman (\%30).

Reklam tavsiye etme oranları: Çalışan; bazen (\%48)-hiçbir zaman (\%40). Çalışan öğrenci; hiçbir zaman (\%44)-bazen (\%33). Emekli; hiçbir zaman (\%55)-bazen (\%32). Öğrenci; hiçbir zaman (\%43)-bazen (\%27).

En çok ilgilenilen reklam türleri: Çalışan; giyim (\%23)-teknoloji (\%17)-gıda (\%14)-kamu spotları (\%13)-turizm (\%11)-eğitim-kültür (\%10)-otomotiv (\%7)eğlence (\%3)-politik (\%2)-ulaşım (\%1). Çalışan öğrenci; teknoloji (\%23)-giyim (\%17)-eğlence (\%15)- gıda (\%12)-eğitim-kültür ve turizm (\%11)-otomotiv ve politik (\%5)-ulaşım ve kamu spotları (\%2). Emekli; eğitim-kültür ve teknoloji (\%18)-gıda, giyim ve otomotiv (\%14)- turizm (\%9)-ulaşım, politik ve kamu spotları (\%5)-eğlence (\%0). Öğrenci; giyim (\%28)- teknoloji (\%23)-eğlence (\%15)-eğitim-kültür (\%13)-otomotiv (\%7)-gıda (\%6)-turizm (\%4)-kamu spotları (\%2)-politik (\%1)-ulaşım (\%0).

Reklamların en çok hangi mecralardan alındığına ilişkin algı: Çalışan; sosyal medya (\%52)-televizyon-radyo (\%39)-SMS-E-posta (\%4). Çalışan öğrenci; sosyal medya (\%65)- televizyon-radyo (\%18)-yazılı basin (gazete-dergi vs.) (\%6). Emekli; sosyal medya (\%41)- televizyon-radyo (\%36)-SMS-E-posta (\%14). Öğrenci; sosyal medya (\%68)-televizyon-radyo (\%21)-yazılı basın (gazete-dergi vs.) (\%4). 
En çok etkilenilen reklamların yayın mecraları: Çalışan; televizyon-radyo (\%50)- sosyal medya (\%39)-yazılı basın (gazete-dergi vs.) (\%7). Çalışan öğrenci; sosyal medya (\%59)-televizyon-radyo (\%23)-yazılı basın (gazete-dergi vs.) (\%8). Emekli; sosyal medya ve televizyon-radyo (\%41)-SMS-E-posta (\%9). Öğrenci; sosyal medya (\%64)-televizyon-radyo (\%23)-yazılı basın (gazete-dergi vs.) ve afiş-billboard-pano (\%4).

Sosyal medyada zorunlu izletilen reklamlara rastlandığında: Çalışan; sinirlenirim (\%37)-hoşlanmam (\%33)-önemsemem (\%16). Çalışan öğrenci; hoşlanmam (\%35)- sinirlenirim (\%30)-önemsemem ve öylesine izlerim (\%14). Emekli; sinirlenirim (\%50)- alışveriş kararlarımı etkilemez (\%18)-hoşlanmam ve öylesine izlerim (\%14). Öğrenci; hoşlanmam (\%30)-sinirlenirim (\%28)önemsemem (\%21).

En az etkilenilen reklamların yayınlandığı mecralar: Çalışan; SMS-E-posta (\%29)- sosyal medya (\%25)-yazılı basın (gazete-dergi vs.) (\%20). Çalışan öğrenci; SMS-E-posta (\%32)-yazılı basın (gazete-dergi vs.) (\%21)-doğrudan (broşür-vitrin-ürün ambalajı) (\%18). Emekli; sosyal medya (\%41)-televizyonradyo (\%32)-afiş-billboard-pano (\%14). Öğrenci; sosyal medya ve SMS-Eposta (\%25)-yazılı basin (gazete-dergi vs.) (\%17)-televizyon-radyo (\%13).

\section{Sonuç ve Öneriler}

Çalışmanın bulgularından en göze çarpanı sosyal medya mecralarında zorunlu olarak izlettirilen reklamların tüketiciler tarafından ağırlıklı olarak hoşlanmama ve sinirlenme gibi tepkilerle karşılandığ1 gözlemlenmiştir. Yine önemli bir sonuç olarak sosyal medya zorunlu reklamlarının yararlı olmadığına yönelik olarak ağırlıklı görüşün varlığından bahsedilebilir. Ayrıca reklamların gerçekçiliğine ilişkin algılamanın da negatif yönde olduğu belirtilmelidir. Genel olarak en fazla ilgi çeken reklam türleri içinden giyim ve teknoloji konulu olanların öne çıktığı; bu reklamların kişilere en fazla sosyal medya mecraları ile ulaşabildiği gözlemlenmektedir. Kişilerin en fazla etkilendiklerini düşündükleri reklam mecraları sosyal medya ve radyo-televizyon olarak öne çımaktadır. Kişilerin en az etkilendikleri reklam mecraları da öncelikle SMS-E-posta sonra ise sosyal medya olarak sıralanmıştır. Kişilerin en çok etkilendikleri reklam mecralarının da sosyal medya mecraları olduğu; dolayısıyla kişilerin en çok etkilendiği reklam mecrası ve kişilerin en az etki- 
lendiği ikinci reklam mecrasının sosyal medya reklamları olduğu görülmektedir. Birbirine tezat gibi görünen bu iki sonuç; her durumda kişilere en fazla reklam ulaşım mecrasının büyük oranda (\%63) sosyal mecralarından oluşması ile açıklanabilir. Bu sonuçlardan hareketle, sosyal medya mecralarının reklamların etkinliği, yaygınlığı (ulaşabilirliği) ve konusunda en etkili reklam mecrası olduğu gözlemlenmiştir. Ancak sosyal medya ortamında zorunlu olarak izlenmek zorunda kalınan reklamlar karşısında kişiler; yaş, cinsiyet ve diğer tüm ayrımlar için geçerli olmak üzere olumsuz olarak karşılamaktadırlar. Ayrıca zorunlu reklamların yararlılı̆̆ konusunda da ağırlıklı olarak negatif görüşler gözlemlenmiştir. Dolayısıyla sosyal medya zorunlu reklamları ile ilgili ilgililerin reklam yönetimlerine yönelik olarak başka çözümler bulması önerilir.

SMS-E-posta/doğrudan ve afiş-billboard-pano reklamlarının en az etkilenilen reklam ecraları olması nedeni ile yine ilgili tarafların bu durumu dikkate alarak gözden geçirmeleri; etkinliği artırıcı ya da alternatiflerin değerlendirilmesi ya da sadece bazı durumlar için tercih edilmeleri gibi bir başka yöntem belirlemeleri tavsiye edilebilir.

Tüm platform reklamları için alışveriş kararlarını etkileme, reklamların gerçekçiliği, reklamların bir başkasına tavsiye edilmesi gibi hususlarda katılımcılar ağırlıklı olarak negatif görüş bildirmişlerdir. Bu gözlemden hareketle ilgililer ciddi endişeler olarak değerlendirilebilecek bu hususlarda etkililiği ve güvenirliği artırıcı, daha olumlu algı sonuçları oluşturabilmek için teknik ve yöntem geliştirmeleri tavsiye olunur.

Konuya ilişkin araştırma yapmak isteyen araştırmacılara yönelik olarak; sosyal medya mecralarında yaymlanmakta olan ve zorunlu olarak izlettirilen reklamlar ile bu reklam türlerinin etkilediği satın alma eğilimi ile farklı yaş/sosyal statü gruplarının satın alma kararlarına çapraz etkileri çalışma konusu yapılabilir (örneğin zorunlu reklam konusu olan ürünün/ürün grubunun aile alışveriş kararları üzerinde, öğrenci/emekli kişilerin etkisi).

Reklamcılık sektörüne yönelik olarak, bazı reklam mecralarının etkililiği son derece düşük görülürken, sosyal medya gibi reklam mecralarının yüksek seviyeli erişimine rağmen güvenirlik alışveriş kararlarını etkilemek gibi hususlarda benzer başarıyı gösterememesi gibi hususlarda iyileştirme çalışmaları yapmaları tavsiye edilebilir. Sosyal medya ortamlarında zorunlu olarak sunulan reklamlar önemli oranda olumsuz tepkilere neden olabilmektedir. Dolayısıyla sosyal medya ortamlarında reklamların izlenmesi için farklı ve 
katılımcı yöntemleri geliştirmeleri önerilebilir. Bu tür reklamlar için fayda/maliyet analizlerinin reklam veren firmalar için detaylıca yapılması tavsiye edilebilir. Malum olunduğu üzere bilişim, dijital ve internet dönemi ile beraber sosyokültürel, ekonomi, ticaret, iletişim ve yönetim bilimi başta olmak üzere neredeyse tüm temel taşlar yerinden oynayarak yeniden yap1lanma sürecine girmiştir. Bu bakımdan yeni eğilimler ve yeni tekniklerin oluşması kaçınılmaz görülmektedir. Bu yeni temel taşlar üzerinde yükselmekte olan yeni yapı içerisinde reklam etkinliğini artıracak hayal gücünü zorlayıcı ve sofistike yeni teknik ve araçların kullanılması için istikametin yeniden belirlenmesi tavsiye edilebilir. 


\title{
EXTENDED ABSTRACT
}

\section{A Research On The Effectiveness And Perception Of Advertising Advertisements On Social Media And Some Media}

\author{
Alpaslan Doğan - İpek Fatma Çevik \\ Ĭgdır Üniversitesi
}

Advertising is one of the important activities for businesses and society. In addition, advertising broadcasting channels are increasingly diverse. One of these advertising channels is social media ads. Social media ads, which are becoming more and more important and can reach more consumers every day, are becoming increasingly important among all advertising channels. For this reason, it was deemed necessary to investigate the effectiveness levels of the advertisements published in other channels and the advertisements published in social media channels according to their media and demographic characteristics. In addition, perceptions towards mandatory advertisements, which are applied especially in social media advertisements, have also been identified as research subjects.

With the study, various kinds of advertisements published in social media and other channels; It aims to reveal the effect of consumers on purchasing decisions and their behaviors in the face of the presentation of advertisements.

The research, in which quantitative methods were used, was conducted by obtaining primary type data through a questionnaire. 442 participants were participated in the study and validity and reliability tests were performed. Obtained from 442 participants; Primary data collected through a questionnaire with 10 questions; It was analyzed with the SPSS program and the Numerical Table Program was also used. The scale expressions are at the Likert-5 level (never-sometimes-have no idea-usually-always) and also include categorical questions. The reliability coefficient (Cronbach's Alpha) for the scale questions was found to be 0.690 . Therefore, it has been concluded that the scale used in the study is at a sufficient level for its reliability. As a result 
of the factor analysis, KMO value was 0.77 ; The Barlett test $\mathrm{p}$ value was calculated as 0.000 , and it was observed that the explanation ratio of the model was $55.127 \%$ and the eigenvalues for all statements were greater than 0.50 . Therefore, it was concluded that the validity and reliability levels of the scale were at the appropriate level.

The most striking of the findings of the study, it was observed that the advertisements that are watched on social media channels are mostly met with negative reactions such as "dislike" and "annoyance" by consumers. Again, as an important result, it can be said that there is a predominant opinion that social media mandatory ads are not useful. It should also be noted that the perception of the realism of advertisements is also negative. In general, among the most popular advertising types, clothing and technology ones stand out; It is observed that advertisements are mostly social media channels. Social media and radio-television are the advertising channels that people think are the most affected. The advertising channels that people were least affected by were listed as SMS-E-mail and then social media. The advertising channels that people are most affected by are also social media channels; Therefore, it is observed that the advertising channels most affected by people and social media advertisements are the second advertising channels that are the least affected. These two results that seem to be in contrast to each other; In any case, it can be explained by the fact that the most advertising transportation channels (63\%) consist of social platforms. Based on these results, it has been observed that social media platforms are the most effective advertising channels in terms of the effectiveness, prevalence (accessibility) of advertisements. However, in the face of the obligatory advertisements in the social media environment, people; They regard it negatively, valid for age, gender and all other distinctions. In addition, mainly negative opinions were observed about the usefulness of compulsory advertisements. Therefore, it is recommended that those concerned with social media mandatory ads find other solutions for ad management. Due to the fact that SMS-E-mail / direct and poster-billboard-billboard advertisements are the least affected advertising channels, the related parties should review this situation, determine another method such as evaluating alternatives to increase efficiency or choosing only for some cases. can be recommended. Participants mostly expressed negative opinions on issues such as influencing shopping decisions for all platform advertisements, the realism of the ads, and recommending 
the advertisements to others. Based on this observation, it is thought that the application of techniques and methods may be beneficial in order to increase the effectiveness and reliability and to create more positive perception results in these issues, which can be considered as serious concerns. For researchers who want to do research on the subject; The advertisements that are published on social media platforms and are forced to watch, and the cross effects of the purchasing tendency affected by these types of advertisements and the purchasing decisions of different age / social status groups can be studied (for example, in the decision to buy the product / product group subject to mandatory advertising, students / retired persons effect). It is thought that the study may be important for advertisers, advertising agencies, advertisers and consumers in general.

Regarding the advertising industry; While the effectiveness of some advertising channels is extremely low, it may be recommended that advertising channels such as social media do not show similar success in matters such as affecting the reliability shopping decisions despite their high-level access. Compulsory advertisements in social media environments can cause significant negative reactions. Therefore, it may be suggested that they develop different and participatory methods for watching ads in social media environments. For such advertisements, it may be recommended to make detailed benefit / cost analyzes for advertisers. As it is known, along with the informatics, digital and internet era, almost all the foundation stones, especially sociocultural, economics, commerce, communication and management science, have entered the process of restructuring. In this respect, the emergence of new trends and new techniques seems inevitable. Within the new structure rising on these new foundation stones, it may be advisable to redefine the direction to use sophisticated new techniques and tools that will increase the effectiveness of advertising.

\section{Kaynakça / References}

Dijiloepedi. (t.y). 2019 Dünya internet kullantmı ve sosyal medya istatistikleri-4. çeyrek raporu. $\quad$ https://dijilopedi.com/2019-dunya-internet-kullanimi-ve-sosyalmedya-istatistikleri-4-ceyrek-raporu adresinden erişilmiştir.

Chan, C. (2011). Using online advertising to increase the impact of a library facebook page. Library Management. 32(4/5), 361-370. 
Choi, S. Y., Stahl, D. O. ve Whinston, A. B. (1997). The economics of electronic commerce. Indianapolis: Macmillan Technical Publishing.

Çivrilli, N. (1993). Kıyısından-köşesinden reklamcılık. İstanbul: Gündem Yayınları.

Cook, G. (2001). The discourse of advertising. 2nd edition. London: Routledge.

Faber, R. J. ve Lee, M. ve Nan, X. (2004). Advertising and the consumer information environment online. American Behavioral Scientist, 48(4), 447-466.

Fidan, B. (2007). Reklam ve karikatür. İstanbul: Bamm Yaynevi.

Giri, A. V. (2015). Advertising and consumer behaviour. International Journal of Multifaceted and Multilingual Studies, 1(4), 1-9.

Goddard, A. (2001). The language of advertising. London: Taylor\&Francis e-library.

Gülsoy, T. (1999). Ingilizce-Türkçe reklam terimleri ve kavramları sözlüğü. İstanbul: Adam Yayınları.

Gün, F. S. (1999). Elektronik reklamcllk ve uygulamaları. Ankara: Tüm Ofset.

Gürgen, H. (1990). Reklamcılık ve metin yazarlığı. Anadolu Üniversitesi Yayınları.

Gürüz, D. (1999). Reklam yönetimi. İzmir: Ege Üniversitesi Basımevi, Punto Yayınları.

İyiler, Z. (2009). Elektronik ticaret ve pazarlama ihracatta internet zamanı. Ankara: DTP.

Jerome, T., Shan, L. W., ve Khong, K. W. (2010). Online advertising: A study on Malaysian consumers. http://dx.doi.org/10.2139/ssrn.1644802

Kannan, R. ve Tyagi, S. (2013). Use of language in advertisements. English for Specific Purposes World, 37(13), 1-10.

Kaplan, A. M. ve Haenlein, M. (2010). Users of the world, unite! The challenges and opportunities of social media. Business Horizons, 53 (1), 59-68.

Kaye, B. K. ve Medoff, N. J. (2001). Just a click away: Advertising on the internet. Massachusetts: Allyn and Bacon.

Kırcova, İ. (2005). Internette pazarlama. İstanbul: Beta Basım Yayın Dağıtım.

Kirtiş, A. K.ve Karahan, F. (2011). To be or not to be in social media arena as the most cost-efficient marketing strategy after the global recession. 7 th International Strategic Management Conference. In Proceding of Social and Behaviorial Sciences, içinde (s.260-268).

Kocabaş, F. ve Elden, M. (1997). Reklamcılık. İstanbul: İletişim Yayınları.

Korgaonkar, P. ve Wolin, L. D. (2002). Web usage, advertising, and shopping: Relationship patterns. Internet Research, 12(2), 191-204.

Kotler, P. (2003). Pazarlama yönetimi. (N. Muallimoğlu, Çev.). İstanbul: Beta Basım Yayın.

Küçükerdoğan, R. (2009). Reklam nasıl çözümlenir. İstanbul: Beta Yayınları.

Lance, S. ve Woll, J. (2006). Reklamcılı̆̆ın turuncu kitabı. İstanbul: Mediacat Yayınları. 
Li, H., Edwards, S. M. ve Lee, J.H. (2002). Measuring the intrusiveness of advertisements: Scale development and validation. Journal of Advertising. 31(2), 37-47. Mucuk, İ. (1999). Pazarlama ilkeleri. İstanbul: Türkmen Kitabevi.

Odabaşı, Y. (1995). Pazarlama iletişimi. Anadolu Üniversitesi Yayınları.

Onat, F. ve Alikılıç, Ö. A. (2008). Sosyal ağ sitelerinin reklam ve halkla ilişkiler ortamları olarak değerlendirilmesi. Journal of Yaşar University, 3(9).

Richards, B., MacRury, I. ve Botterill, J. (2000). The dynamics of advertising (Vol. 1). London: Psychology Press.

Ring, J. (1996). Reklam dünyasının iç yüzü. (S. Komçez, Çev.). 1. Baskı. İstanbul: Financial Times Milliyet Yayınları.

Rutherford, P. ve Gerçekler, M. K. (1996). Yeni ikonalar: Televizyonda reklam sanatı. İstanbul: YKY.

Sayımer, İ. (2009). Sanal ortamda stratejik halkla ilişkiler yönetimi. İstanbul: Beta Yayınları.

Schlosser, A. E., Shavitt, S. ve Kanfer, A. (1999). Survey of internet users' attitudes toward internet advertising. Journal of Interactive Marketing, 13(3), 34-54.

Shim, J. K., Qureshi, A. A., Siegel, J. G. ve Siegel, R. M. (2013). The international handbook of electronic commerce. New York: Routledge.

Tokol, T. (1996). Pazarlama yönetimi. Uludağ Üniversitesi.

Tolungüç, A. (1999). Turizmde tanıtım ve reklam. Ankara: MediaCat Yayınları,

Uusitalo, L. (2010). Advertising and consumer behavior chapter 28. The Authors and Student Litteratur. 553-572.

Weilbacher, W. M. (2001). Point of view: Does advertising cause a 'Hierarchy of Effects?'. Journal of Advertising Research, 41(6), 19-26.

Yaylacı, G. Ö. (1999). Reklamda stratejilerle yönetim. İstanbul: Alfa Yayınları.

Yeshin, T. (2006). Advertising. London: Thompson Learning.

Tavşancıl, E. (2010). Tutumların ölçülmesi ve SPSS ile veri analizi. Ankara: Nobel Yayın Dağtim.

Tezbaşaran, A. A. (1997). Likert tipi ölçek geliştirme kılavuzu. Ankara: Türk Psikologlar Derneği.

Trompenaars, F. ve Voerman, E. (2009). Servant-leadership across cultures: Harnessing the strengths of the world's most powerful management philosophy. New York: The McGraw-Hill Companies.

Vinod, S. ve Sudhakar, B. (2011). Servant leadership: A unique art of leadership, Interdisciplinary Journal of Contemporary Research in Business, 2(11), 456-467.

Yılmaz, V. ve Çelik, H. E. (2009). Lisrel ile yapısal eşitlik modellemesi i temel kavramlar, uygulamalar, programlama. Ankara: Pegem Akademi Yayıncılık. 


\section{Kaynakça Bilgisi / Citation Information}

Doğan, A. ve Çevik, İ. F. (2020). Sosyal medyada ve diğer bazı mecralarda yayınlanan reklamların tüketiciler üzerindeki etkililiği ve algılanışı üzerine bir araştırma. OPUS-Uluslararası Toplum Araştırmaları Dergisi, 16(32), 4809-4839. DOI: 10.26466/opus.707041 